\title{
California GAMA Special Study: Stable Isotopic Composition of Boron in Groundwater - San Diego County Domestic Well Data
}

Gary R. Eppich, Michael J. Singleton, Josh B. Wimpenny*, Qing-zhu Yin*, and Bradley K. Esser

Lawrence Livermore National Laboratory *University of California, Davis

August, 2012

Final report for the California State Water Resources Control Board GAMA Special Studies Task 10.4 : Development of New Wastewater Indicator Methods 


\section{Disclaimer}

This document was prepared as an account of work sponsored by an agency of the United States government. Neither the United States government nor Lawrence Livermore National Security, LLC, nor any of their employees makes any warranty, expressed or implied, or assumes any legal liability or responsibility for the accuracy, completeness, or usefulness of any information, apparatus, product, or process disclosed, or represents that its use would not infringe privately owned rights. Reference herein to any specific commercial product, process, or service by trade name, trademark, manufacturer, or otherwise does not necessarily constitute or imply its endorsement, recommendation, or favoring by the United States government or Lawrence Livermore National Security, LLC. The views and opinions of authors expressed herein do not necessarily state or reflect those of the United States government or Lawrence Livermore National Security, LLC, and shall not be used for advertising or product endorsement purposes.

\section{Auspices Statement}

This work performed under the auspices of the U.S. Department of Energy by Lawrence Livermore National Laboratory under Contract DE-AC52-07NA27344. 


\section{GAMA: GROUNDWATER AMBIENT \\ Monitoring \& Assessment Program \\ SPECIAL STUdY}

\section{California GAMA Special Study: Stable Isotopic Composition of Boron in Groundwater - San Diego County Domestic Well Data}

By Gary R. Eppich, Michael J. Singleton, Josh B. Wimpenny*, Qing-zhu Yin*, and Bradley K. Esser

Lawrence Livermore National Laboratory

*University of California, Davis

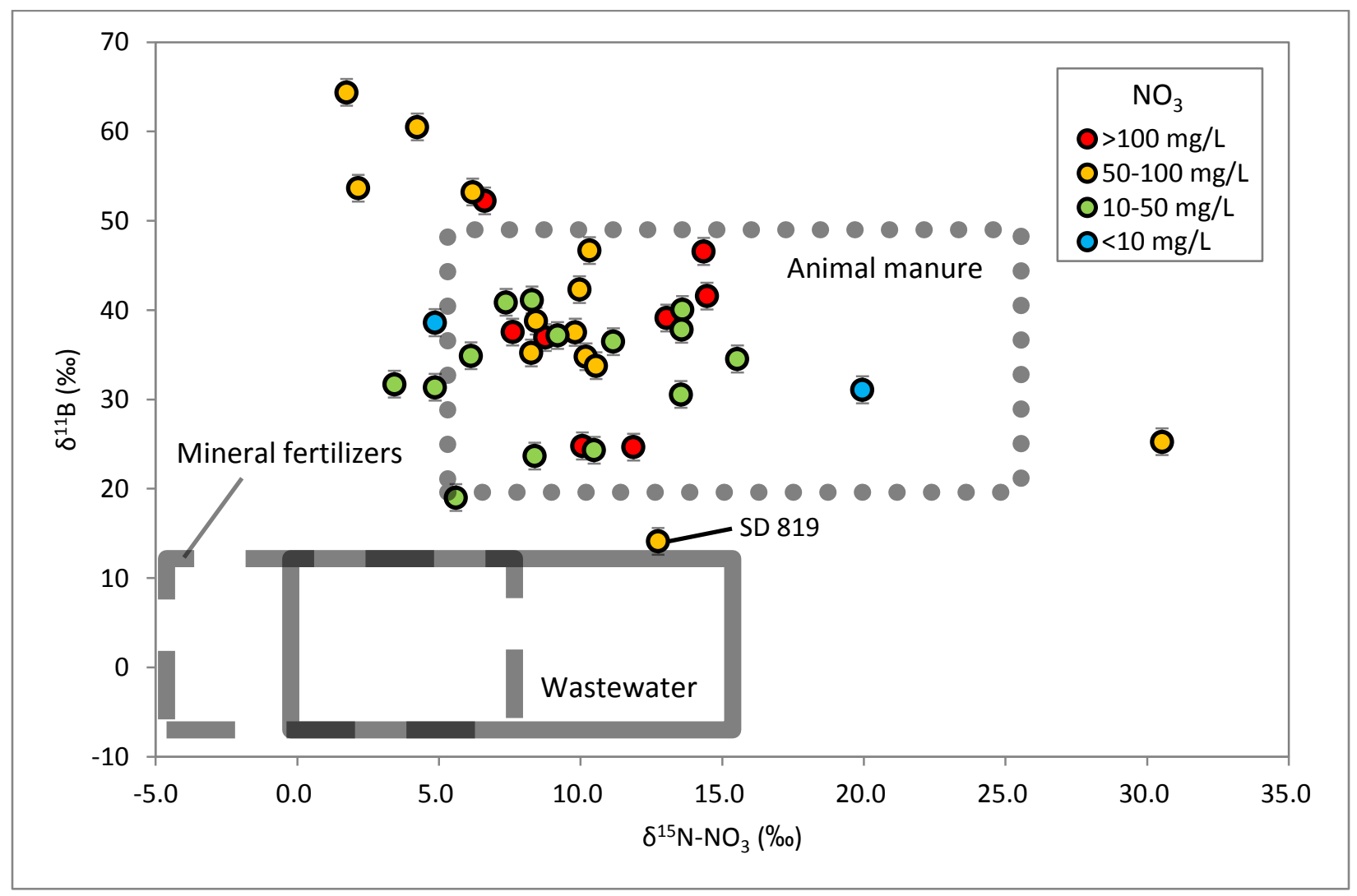

Final Report for GAMA Special Studies Task 10.4

Development of New Wastewater Indicator Methods

LLNL-TR-533174

Prepared in cooperation with the California State Water Resource Control Board September 2011 
Eppich, Singleton, Wimpenny, Yin, and Esser (2012) LLNL-TR-533174

Suggested citation:

Eppich, G.R., Singleton, M.J., Wimpenny, J.B., Yin, Q.-Y., and Esser, B.K. 2012. California GAMA Special Study: Stable Isotopic Composition of Boron in Groundwater - San Diego County Domestic Well Data, LLNL-TR-533174, 23 pages. 


\section{INTRODUCTION}

The Groundwater Ambient Monitoring and Assessment (GAMA) Program is a comprehensive groundwater quality monitoring program for the state of California. Managed by the California State Water Resources Control Board (SWRCB), the goals of the Program are twofold: to improve statewide groundwater monitoring, and to increase the availability of groundwater quality information to the public. The Domestic Well Project has sampled 137 wells in San Diego County in an effort to assess the quality of these unregulated domestic use water sources. Lawrence Livermore National Laboratory (LLNL) performed isotopic analyses of domestic well water samples for the SWRCB; this study summarizes the results of measurements of the isotopic composition of dissolved boron in groundwater in 56 wells, and provides some interpretations regarding the significance of these findings. These data, in conjunction with water and nitrate isotopic composition data (Singleton et al., 2010), are useful for determining the source(s) of nitrate in potentially-contaminated San Diego County groundwater reservoirs.

The isotopic composition of dissolved boron $\left(\delta^{11} \mathrm{~B}\right)$ in sampled San Diego County groundwaters varies from -0.8 to $+64.4 \%$. Most sampled groundwaters ( 44 of 56 ) have $\delta^{11} \mathrm{~B}$ values between +20 and $+50 \%$ o, within the isotopic composition range characteristic of animal manure. These samples tend to have high nitrate concentrations ( $>50 \mathrm{mg} / \mathrm{L}$ as $\mathrm{NO}_{3}$ ) These results are consistent with isotopic composition of nitrogen in nitrate $\left(\delta^{15} \mathrm{~N}\right)$ data from Singleton et al. (2010), indicating that animal manure is a primary source of nitrate in most groundwaters measured in this study. Seven samples have $\delta^{11} B$ values less than $+20 \%$, outside of the animal manure $\delta^{11} \mathrm{~B}$ range. These groundwaters tend to have low nitrate concentrations $(<10 \mathrm{mg} / \mathrm{L}$ as $\mathrm{NO}_{3}$ ), although two have nitrate concentrations greater than $10 \mathrm{mg} / \mathrm{L}$, suggesting that wastewater may partially contribute to their nitrate budget. No samples measured in this study have boron or nitrate isotopic compositions consistent with a mineral fertilizer nitrate source. Five sampled groundwaters have $\delta^{11} \mathrm{~B}$ values greater than $+50 \%$, significantly higher than any known anthropogenic boron source. More work is needed to assess the source of nitrate and boron in the greater than $+50 \%$ groundwaters.

\section{SAMPLES AND METHODS}

The analytical methods used in this study are described in detail in Eppich et al. (2011). In short, groundwater samples were collected unfiltered from wells in clean $50 \mathrm{~mL}$ polyethylene centrifuge tubes, following the methods of Singleton et al. (2010). Boron concentrations, $\mathrm{NO}_{3}$ concentrations, and other water chemistry data used in this study were measured by laboratories subcontracted by the SWRCB. These data were obtained from the Geotracker GAMA Database.

For isotopic analysis, boron was chemically separated from samples using an ion-exchange technique (using the boron-specific ion-exchange resin Amberlite IRA-743) adapted from Lemarchand et al. (2002) and Guerrot et al. (2011), and described in Appendix A of Eppich et al. (2011). Isotopic composition measurements were performed using a standard-sample-standard bracketing routine on a Thermo Neptune MC-ICP-MS at University of California - Davis 
(Appendix B, Eppich et al. 2011). The boron isotopic standard NIST SRM 951 was measured before and after each sample measurement; these data were used to correct for instrumental mass bias. Due to the tendency of boron to sorb to front-end components of the mass spectrometer (the "memory effect"), background corrections are typically non-negligible for boron isotopic measurements by ICP-MS (Al-Ammar et al., 2000). Blank solutions were measured before each sample and standard measurement. Mass 11 blank signal intensity was typically less than $5 \%$ of mass 11 sample and standard intensity; mass 10 blank signal intensity was typically $<1 \mathrm{mV}$ on a Faraday detector. To assess whether isotopic fractionation occurred due to chemical purification (Lemarchand et al., 2002), boron isotopic standards NIST SRM 951, IAEA-B-2, and IAEA-B-3 were chemically purified and analyzed with each sample batch. Quality control results are presented in Tables 1 through 3.

Boron isotope ratios were calculated relative to NIST SRM 951 using Eq. 1,

Equation 1:

$$
\delta^{11} B_{\text {sample }}(\%)=\left[\frac{R_{\text {sample }}}{\left(R_{\text {SRM } 951(1)}+R_{\text {SRM 951 (2) }}\right) \div 2}-1\right] \times 1000
$$

where $R_{\text {sample }}$ is the sample ${ }^{11} B /{ }^{10} B$ ratio and $R_{\text {SRM } 951 \text { (1) }}$ and $R_{\text {SRM } 951 \text { (2) }}$ are ${ }^{11} B /{ }^{10} B$ ratios of NIST SRM 951 measured before and after $R_{\text {sample. }}$ All ratios are corrected for blank. Isotopic composition is reported using delta notation $\left(\delta^{11} \mathrm{~B}\right)$ in per mil (\%o) relative to NIST SRM 951.

We selected a subset of 56 samples to analyze for $\delta^{11} B$. Samples were chosen to represent a wide geographic distribution throughout San Diego County. Furthermore, we chose samples for $\delta^{11} \mathrm{~B}$ analysis that had been previously measured for nitrate isotopic composition by Singleton et al. (2010). These samples have high nitrate concentrations (>10 mg/L) relative to samples not chosen for analysis. Therefore, $\delta^{11} \mathrm{~B}$ results reported here reflect sampling bias towards high$\mathrm{NO}_{3}$ samples.

Quality Assurance/Quality Control (QA/QC) standards, established for $\delta^{11} \mathrm{~B}$ analyses by Eppich et al. (2011), were met for all sample batches processed through boron purification chemistry. Measurements of purified NIST SRM 951 were within $0.75 \%$ of the certified value $\left(\delta^{11} \mathrm{~B}=0 \%\right.$, by definition). We conservatively report uncertainty of $\delta^{11} \mathrm{~B}$ as $\pm 1.5 \%$. Analytical uncertainty was typically better than $0.25 \%$. Groundwater boron isotopic standards IAEA-B-2 and IAEA-B3, also purified, were typically within $1.5 \%$ of recommended values (Gonfiantini et al., 2003). In one case, the measured isotopic composition of IAEA-B-2 was $2.6 \%$ o lower than the recommended value (Batch 6 in Table 1). However, measurements of NIST SRM 951 and IAEAB-3 were within specifications for this batch, suggesting that this measurement is an outlier.

Field duplicates of SD 831 were analyzed for boron isotopic composition (Table 2), and were reproducible to better than $1.5 \%$. Procedural duplicates were performed for a minimum of one sample in each batch (Eight duplicates total; Table 3). Duplicates were typically reproducible to better than $1.5 \%$. In two cases (SD 843 and SD 946), the difference between 
the two measurements was 2.34 and $2.27 \%$, respectively. These results suggest that sample heterogeneity (possibly related to the fraction of colloidal material aliquoted in each replicate) may be responsible for slight deviations in boron isotopic composition. Although these deviations are not significant enough to effect the conclusions of this report, they do validate our decision to consider a conservative approach to uncertainty.

\section{RESULTS AND DISCUSSION}

Boron isotopic composition results for San Diego County groundwater samples are summarized in Table 4 and Figure 1. Boron isotopic composition in sampled groundwaters varies from -0.8 to $+64.4 \%$. We observe a much larger spread in San Diego County groundwater $\delta^{11} \mathrm{~B}$ than reported in similar studies of different regions (e.g. Widory et al., 2004; 2005). Most sampled groundwaters ( 44 of 56 ) fall within +20 to $+50 \%$, although five have $\delta^{11} \mathrm{~B}$ values greater than $+50 \%$ and seven have $\delta^{11} \mathrm{~B}$ values less than $+20 \%$. The relationship between $\delta^{11} \mathrm{~B}$ and $\mathrm{B}$ is complex. Samples with $\delta^{11} B$ less than $+20 \%$ tend to have the highest B $(>200 \mu \mathrm{g} / \mathrm{L})$, although some samples with higher $\delta^{11} B$ also have high B concentration. Samples with the lowest $B(<50$ $\mu \mathrm{g} / \mathrm{L}$ ) tend to have $\delta^{11} \mathrm{~B}$ values between +20 and $+40 \%$. Boron concentration and isotopic composition of the low-B samples most closely resembles that of atmospheric precipitation, which can be highly variable in $\delta^{11} \mathrm{~B}$, but typically has low $\mathrm{B}$ concentrations. Most samples from this study with high $\mathrm{NO}_{3}\left(>50 \mathrm{mg} / \mathrm{L}\right.$ ) have $\delta^{11} \mathrm{~B}$ values greater than $+20 \%$.

Boron isotopic composition data are most useful for constraining nitrate sources when considered alongside other isotopic data, particularly $\delta \mathrm{D}$ and $\delta^{18} \mathrm{O}$ in $\mathrm{H}_{2} \mathrm{O}$, and $\delta^{15} \mathrm{~N}$ and $\delta^{18} \mathrm{O}$ in $\mathrm{NO}_{3}$ (Widory et al., 2004; 2005). Singleton et al. (2010) reported water and nitrate isotopic results for the same San Diego County groundwater samples measured in this study; we present plots of those data here (Fig. 2 and 3). Water isotopic data generally plot along the Global Mean Water Line (Craig, 1961), indicating that these groundwaters have a meteoric origin, and were not strongly affected by evaporation prior to recharge.

Figure 3 shows the isotopic composition of potential nitrate sources based on literature data and the global variation of $\delta^{18} \mathrm{O}-\mathrm{H}_{2} \mathrm{O}$ in natural waters (Kendall, 1998). In general, the oxygen isotope composition of nitrate $\left(\delta^{18} \mathrm{O}-\mathrm{NO}_{3}\right)$ produced by nitrification of ammonium is correlated with the oxygen isotope composition of ambient water $\left(\delta^{18} \mathrm{O}-\mathrm{H}_{2} \mathrm{O}\right)$. This correlation is due to incorporation of local water and atmospheric oxygen, typically in a 2:1 ratio, during production of nitrate from ammonium. Atmospheric oxygen has a nearly constant $\delta^{18} \mathrm{O}$ value of $23.5 \%$, but the oxygen isotope composition of water is variable. For this reason, it is necessary to calculate the expected ranges of nitrate $\delta^{18} \mathrm{O}$ values $\left(\delta^{18} \mathrm{O}-\mathrm{NO}_{3}\right)$ based on measurements of local water $\delta^{18} \mathrm{O}$ values $\left(\delta^{18} \mathrm{O}-\mathrm{H}_{2} \mathrm{O}\right)$ for sources where nitrification of ammonium is an important process in the production of nitrate. These sources may include nitrate produced in the soil zone, nitrate from nitrification of ammonium fertilizers, and nitrate from ammonium wastes such as septic systems or manure. The range of $\delta^{18} \mathrm{O}-\mathrm{NO}_{3}$ for nitrified sources for this study area is predicted to fall between 0.1 and $5.3 \%$ (shown on the right in Figure 3). This range is calculated based on the measured groundwater $\delta^{18} \mathrm{O}-\mathrm{H}_{2} \mathrm{O}$ values from this study, and assumes a 2:1 ratio of local water and atmospheric oxygen is imparted to the nitrate during nitrification. 
Local water $\delta^{18} \mathrm{O}-\mathrm{H}_{2} \mathrm{O}$ values within \pm 2 standard deviations from the mean $\delta^{18} \mathrm{O}-\mathrm{H}_{2} \mathrm{O}$ value were used to calculate the range of likely $\delta^{18} \mathrm{O}-\mathrm{NO}_{3}$ values. Nitrate may have higher $\delta^{18} \mathrm{O}-\mathrm{NO}_{3}$ values if formed from nitrification in the presence of water with higher $\delta^{18} \mathrm{O}-\mathrm{H}_{2} \mathrm{O}$ values than those measured in this study, such as evaporated soil waters or summer precipitation. The source for nitrate may also be obscured due to denitrification, which leads to higher $\delta^{15} \mathrm{~N}$ and $\delta^{18} \mathrm{O}$ values in the residual nitrate.

Nitrate isotopic data are typically between 0 to $+15 \%$ for $\delta^{15} \mathrm{~N}$ and 0 to $+10 \%$ for $\delta^{18} \mathrm{O}$. A few outliers have higher $\delta^{15} \mathrm{~N}$ and $\delta^{18} \mathrm{O}$ values, possibly due to denitrification. The vast majority of sampled groundwaters have $\delta^{15} \mathrm{~N}$ and $\delta^{18} \mathrm{O}$ values within the ranges of end-member wastewater and animal manure (Fig. 3). Due to the large overlap in $\delta^{15} \mathrm{~N}$ and $\delta^{18} \mathrm{O}$ for wastewater and animal manure, it is difficult to resolve the signatures of these two nitrate sources using nitrate isotopic data alone. Nitrate fertilizer does not appear to be the dominant source of $\mathrm{NO}_{3}$ in these samples because no sampled groundwaters have $\delta^{15} \mathrm{~N}$ and $\delta^{18} \mathrm{O}$ values consistent with synthetic fertilizer $\left(\delta^{15} \mathrm{~N}=-5\right.$ to $+5 \%$, $\delta^{18} \mathrm{O}=+17$ to $+25 \%$; Xue et al., 2009). Two samples fall within the range of values that might be explained by mixing of nitrate fertilizer with a manure or sewage source. Nitrification of ammonia or ammonium fertilizer is also unlikely to be a source since only six samples from this study, and none of the samples with highest $\mathrm{NO}_{3}$ concentrations $(>100 \mathrm{mg} / \mathrm{L}$ ), fall within the range of isotopic compositions that are predicted for these sources $\left(\delta^{15} \mathrm{~N}=-5\right.$ to $+5 \%$, $\delta^{18} \mathrm{O}=+0.1$ to $+5.3 \%$ o) .

Wastewater and animal manure have distinct boron isotopic signatures. Wastewater contains high boron concentration primarily due to the anthropogenic use of boron-bearing detergents. Boron in detergents is derived from borax deposits (often containing other boron-bearing minerals such as kernite and ulexite) with typical $\delta^{11} \mathrm{~B}$ values of -20 to $+10 \%$ (McMullen et al., 1961; Finley et al., 1962; Swihart et al., 1986; Oi et al., 1989), and wastewater $\delta^{11}$ B has been shown to be largely within this range (-8 to +13\%; Vengosh et al., 1994; Bassett et al., 1995; Eisenhut and Heumann et al., 1997; Leenhouts et al., 1998; Vengosh et al., 1999; Widory et al., 2004; Seiler, 2005; Accoe et al., 2008; Tirez et al., 2010). In contrast, measurements of $\delta^{11} B$ in animal manure are typically between +15 to $+50 \%$ (Komor, 1997; Widory et al., 2004; Accoe et al., 2008; Tirez et al., 2010). Although Widory et al. (2004; 2005) subdivide the animal manure signature into cattle, hog, and poultry signatures, these end-member $\delta^{11} \mathrm{~B}$ signatures overlap considerably, are based on only a few measurements, and seem biased towards their highest measured values (which may be an outlier). Therefore, we use $\delta^{11} \mathrm{~B}$ values of +20 to $+50 \%$ for the animal manure range.

Groundwaters measured in this study contain relatively high concentrations of both nitrate and boron relative to typical natural levels $\left(\mathrm{NO}_{3}>50 \mathrm{mg} / \mathrm{L}, \mathrm{B}>10 \mathrm{ug} / \mathrm{L}\right)$. However, not all potential nitrate sources contain high concentrations of boron. Many previous studies have shown that wastewater has high concentrations of both nitrate and boron (approx. 1-5 mg/L of boron; e.g. Vengosh et al., 1994; Eisenhut and Heumann, 1997). Animal manure has also been shown to have high boron concentrations (variable, but with boron concentrations as high as $8 \mathrm{mg} / \mathrm{L}$; Komor, 1997). In contrast, most mineral fertilizers typically have low boron concentrations, excepting rare fertilizers that include boron as a major component (Komor, 1997; Chetelat and 
Gaillardet, 2005; Tirez et al., 2010). The relationship between boron and nitrate in sampled groundwaters can be seen in Figure 4. There is no straightforward relationship between boron and nitrate in these samples. Although there is a broad positive correlation between boron and nitrate concentrations, some samples have high nitrate concentrations and relatively low boron concentrations (albeit higher than typical background boron concentrations of $<10 \mu \mathrm{g} / \mathrm{L}$ ). Conversely, some samples have greatly elevated boron concentrations (>200 $\mu \mathrm{g} / \mathrm{L}$ ), and nitrate concentrations approaching background levels. The high-boron low-nitrate samples have low $\delta^{11} \mathrm{~B}$ values relative to samples with higher nitrate concentrations; this may imply the presence of a second, probably non-anthropogenic boron source.

By combining groundwater $\delta^{15} \mathrm{~N}$ and $\delta^{11} \mathrm{~B}$ data on a single plot, it is possible in some cases to resolve the distinct isotopic signatures of animal manure, wastewater, and mineral fertilizer nitrate sources. To make this determination for San Diego County groundwaters, we use the $\delta^{15} \mathrm{~N}$ data from Singleton et al. (2010) and the $\delta^{11} \mathrm{~B}$ data from this study. Most sampled groundwaters fall within the $\delta^{15} \mathrm{~N}$ and $\delta^{11} \mathrm{~B}$ range of animal manure (Fig. 5), indicating that animal manure is the primary source of nitrate in these groundwaters. Of the samples that plot outside of the animal manure field, only one (SD 819) is within uncertainty of wastewater $\delta^{11} B$ and $\delta^{15} \mathrm{~N}$ ranges. No sampled groundwaters fall within the mineral fertilizers $\delta^{11} \mathrm{~B}$ and $\delta^{15} \mathrm{~N}$ ranges. However, it should be noted that when groundwater contains a mix of nitrate sources, source identification will be biased toward those with the highest concentration of boron.

Nitrate, boron, and $\delta^{11} \mathrm{~B}$ systematics of sampled groundwaters are summarized in Figure 6. Groundwaters with low nitrate concentrations are characterized by low $\mathrm{NO}_{3} / \mathrm{B}$ ratios and $\delta^{11} \mathrm{~B}$ values between +0 and $+50 \%$, while manure-contaminated groundwaters have high $\mathrm{NO}_{3} / \mathrm{B}$ ratios and $\delta^{11} \mathrm{~B}$ values between +20 and $+50 \%$. Variability in the uncontaminated end-member groundwater can be partially explained by the natural variability of precipitation $\delta^{11} \mathrm{~B}$ (RoseKoga et al., 2006). Atmospheric precipitation, ultimately derived from seawater $\left(\delta^{11} \mathrm{~B}=39.6 \%\right.$; Foster et al., 2010), can vary considerably from this starting value due to boron isotopic fractionation caused by evaporation and condensation (Rose-Koga et al., 2006). In most settings, atmospheric precipitation varies from +20 to $+45 \%$, is dependent upon local weather and climate, as well as atmospheric contamination (e.g. Fogg and Duce, 1985; Rose et al., 2000; Chetelat et al., 2005; Rose-Koga et al., 2006; Millot et al., 2010). Bedrock/soil dissolution is another process resulting in the introduction of $\mathrm{B}$ to groundwater. Crystalline bedrock contains boron in concentrations of several $\mu \mathrm{g} / \mathrm{g}$, and with $\delta^{11} \mathrm{~B}$ values of -5 to $+5 \%$ (Palmer and Swihart, 1996 and references therein). Non-marine evaporites $\left(\delta^{11} \mathrm{~B}=-20\right.$ to $+10 \%$ o) are common in some sedimentary settings, and may contribute greatly to the groundwater boron budget. Dissolution of either rock type will load groundwater with boron, resulting in a lowering of groundwater $\delta^{11} \mathrm{~B}$ from precipitation values towards these lower values (Cividini et al., 2010; Negrel et al., 2012). Some boron-rich rock types, such as evaporates, are expected to dominated the boron budget of local groundwaters (Negrel et al., 2012), which may obscure the signature of anthropogenic boron.

Five samples have anomalously high $\delta^{11} \mathrm{~B}$ values (greater than $+50 \%$, Fig. 6), among the highest ever measured in natural waters. Natural sources with such anomalous $\delta^{11} \mathrm{~B}$ signatures, 
such as marine brines and hot springs (Vengosh et al., 1991; Palmer and Swihart; 1996), are unlikely sources of boron in this environment. All five of these samples have $\mathrm{NO}_{3}$ greater than $50 \mathrm{mg} / \mathrm{L}$. There is no known anthropogenic source for boron with such high $\delta^{11} \mathrm{~B}$, although that does not preclude the possibility of one. The upper range of the animal manure $\delta^{11} \mathrm{~B}$ is poorlyknown and may extend to values greater than $+50 \%$ o. More work must be performed to constrain the source(s) of boron and nitrate in these anomalous groundwaters.

\section{CONCLUSIONS}

San Diego County groundwater samples measured in this study vary in boron isotopic composition $\left(\delta^{11} \mathrm{~B}\right)$ from -0.8 to $+64.4 \%$. Most sampled groundwaters have $\delta^{11} \mathrm{~B}$ between +20 and $+50 \%$. There is no simple relationship between $\delta^{11} \mathrm{~B}$ and boron concentration, although the high- $\mathrm{NO}_{3}$ samples tend to have $\delta^{11} \mathrm{~B}$ values greater than $+20 \%$. Nitrogen and oxygen isotopic compositions of nitrate from Singleton et al. (2010) indicate that the primary sources of nitrate are either animal manure or sewage. By combining this data with boron isotope measurements from this study, we determined that animal manure is the most likely primary source of nitrate in most groundwaters. One groundwater (SD 819) may also have a significant wastewater nitrate source. No sampled groundwaters have boron and nitrate isotopic compositions consistent with a mineral fertilizer nitrate source. Five sampled groundwaters have anomalously high $\delta^{11} \mathrm{~B}$ values ( $>50 \%$ ), significantly higher than the known isotopic range of anthropogenic boron. More work must be performed to understand the source of boron and nitrates in these anomalous groundwaters.

\section{ACKNOWLEDGEMENTS}

The authors would like to thank Dr. Ross Williams (LLNL) for his invaluable guidance and advice in the early development of the methods used in this study.

\section{REFERENCES}

Accoe F; Berglund M; Duta S; Hennessy C; Taylor P; Van Hoof K; De Smedt S. 2008. Source apportionment of nitrate pollution in surface water using stable isotopes of $\mathrm{N}$ and $\mathrm{O}$ in nitrate and B: a case study in Flanders (Belgium). JRC Scientific and Technical Reports EUR 23425 EN.

Al-Ammar AS; Gupta RK; Barnes RM. 2000. Elimination of boron memory effect in inductively coupled plasma-mass spectrometry by ammonia gas injection into the spray chamber during analysis. Spectrochimica Acta Part B 55, 629-635.

Bassett RL; Buszka PM; Davidson GR; Chong-Diaz D. 1995. Identification of groundwater solute sources using boron isotopic composition. Environmental Science and Technology 29, 29152922. 
California Department of Health Services Geotracker Database. State Water Resources Control Board of California: Sacramento, CA, 2003. [http://geotracker.swrcb.ca.gov/]. Accessed 15 March 2011.

Chetelat B; Gaillardet J. 2005. Boron isotopes in the Seine River, France: a probe of anthropogenic contamination. Environmental Science and Technology 39, 2486-2493.

Chetelat B; Gaillardet J; Freydier R; Négrel P. 2005. Boron isotopes in precipitation: experimental constraints and field evidence from French Guiana. Earth and Planetary Science Letters 235, 16-30.

Cividini D; Lemarchand D; Chabaux F; Boutin R; Pierret M-C. 2010. From biological to lithological control of the B geochemical cycle in a forest watershed (Strengbach, Vosges). Geochimica et Cosmochimica Acta 74, 3143-3163.

Craig H. 1961. Isotopic variations in meteoric waters. Science 133, 1702-1703.

Eisenhut S; Heumann KG. 1997. Identification of ground water contaminations by landfills using precise boron isotope ratio measurements with negative thermal ionization mass spectrometry. Fresenius Journal of Analytical Chemistry 359, 375-377.

Eppich GR; Wimpenny JB; Yin Q-Z; Esser BK. 2011. California GAMA Special Study: Stable isotopic composition of boron in groundwater - analytical method development, LLNL-TR498360, $29 \mathrm{p}$.

Finley HO; Eberle AE; Rodden CJ. 1962. Isotopic composition of certain boron minerals. Geochimica et Cosmochimica Acta 26, 911-914.

Fogg TR; Duce RA. 1985. Boron in the troposphere: distribution and fluxes. Journal of Geophysical Research 90, 3781-3796.

Foster GL; Pogge von Strandmann PAE; Rae JWB. 2010. Boron and magnesium isotopic composition of seawater. Geochemistry Geophysics Geosystems 11, 10p.

Gonfiantini R and 30 others. 2003. Intercomparison of boron isotope and concentration measurements, Part I: evaluation of results. Geostandards Newsletter 27, 41-57.

Guerrot C; Millot R; Robert M; Negrel P. 2011. Accurate and high-precision determination of boron isotopic ratios at low concentration by MC-ICP-MS (Neptune). Geostandards and Geoanalytical Research 35, 275-284. 
Kendall C. 1998. Tracing nitrogen sources and cycling in catchments. In: Kendall, C. and McDonnell, J.J., eds.), Isotopic Tracers in Catchment Hydrology, Elsevier, New York.

Komor SC. 1997. Boron contents and isotopic compositions of hog manure, selected fertilizers, and water in Minnesota. Journal of Environmental Quality 26, 1212-1222.

Leenhouts JM; Bassett RL; Maddock T. 1998. Utilization of intrinsic boron isotopes as comigrating tracers for identifying potential nitrate contamination sources. Ground Water 36, 240-250.

Lemarchand D, Gaillardet J; Gopel C; Manhes G. 2002. An optimized procedure for boron separation and mass spectrometry analysis for river samples. Chemical Geology 182, 323-334.

McMullen CC; Cragg CB; Thode HG. 1961. Absolute ratio of ${ }^{11} \mathrm{~B} /{ }^{10} \mathrm{~B}$ in Searles Lake borax. Geochimica et Cosmochimica Acta 23, 147-149.

Millot R; Petelet-Giraud E; Guerrot C; Négrel P. 2010. Multi-isotopic composition $\left(\delta^{7} \mathrm{Li}-\delta^{11} \mathrm{~B}-\delta \mathrm{D}-\right.$ $\delta^{18} \mathrm{O}$ ) of rainwaters in France: origin and spatio-temporal characterization. Applied Geochemistry 25, 1510-1524.

Négrel P; Millot R; Guerrot C; Petelet-Giraud E; Brenot A; Malcuit E. 2012. Heterogeneities and interconnections in groundwaters: Coupled B, Li and stable-isotope variations in a large aquifer system (Eocene Sand aquifer, Southwestern France). Chemical Geology 296-297, 83-95.

Oi T; Nomura M; Musashi M; Ossaka T; Okamoto M; Kakihana H. 1989. Boron isotopic compositions of some boron minerals. Geochimica et Cosmochimica Acta 53, 3189-3195.

Palmer MR; Swihart GH. 1996. Boron isotope geochemistry: an overview. Reviews in Mineralogy 33, 709-744.

Rose EF; Carignan J; Chaussidon M. 2000. Transfer of atmospheric boron from the oceans to the continents: an investigation using precipitation waters and epiphytic lichens. Geochemistry Geophysics Geosystems 1.

Rose-Koga EF; Sheppard SMF; Chaussidon M; Carignan J. 2006. Boron isotopic composition of atmospheric precipitations and liquid-vapour fractionations. Geochimica et Cosmochimica Acta 70, 1603-1615.

Seiler RL. 2005. Combined use of ${ }^{15} \mathrm{~N}$ and ${ }^{18} \mathrm{O}$ of nitrate and ${ }^{11} \mathrm{~B}$ to evaluate nitrate contamination in groundwater. Applied Geochemistry 20, 1626-1636. 
Singleton MJ; Roberts SR; Esser BK. 2010. California GAMA Domestic Wells Data Report: Isotopic Data for San Diego County, LLNL-TR-427960, 12p.

Swihart GH; Moore PB; Callis EL. 1986. Boron isotopic composition of marine and nonmarine evaporite borates. Geochimica et Cosmochimica Acta 50, 1297-1301.

Tirez K; Brusten W; Widory D; Petelet E; Bregnot A; Xue D; Boeckx P; Bronders J. 2010. Boron isotope ratio $\left(\delta^{11} \mathrm{~B}\right)$ measurements in Water Framework Directive monitoring programs: comparison between double focusing sector field ICP and thermal ionization mass spectrometry. Journal of Analytical Atomic Spectrometry 25, 964-974.

Vengosh A; Barth S; Heumann KG; Eisenhut S. 1999. Boron isotopic composition of freshwater lakes from central Europe and possible contamination sources. Acta Hydrochimica et Hydrobiologica 27, 416-421.

Vengosh A; Chivas AR; McCulloch MT; Starinsky A; Kolodny Y. 1991. Boron isotope geochemistry of Australian salt lakes. Geochimica et Cosmochimica Acta 55, 2591-2606.

Vengosh A; Heumann KG; Juraske S; Kasher R. 1994. Boron isotope application for tracing sources of contamination in groundwater. Environmental Science and Technology 28, 19681974.

Widory D; Kloppman W; Chery L; Bonnin J; Rochdi H; Guinamant J-L. 2004. Nitrate in groundwater: an isotopic multi-tracer approach. Journal of Contaminant Hydrology 72, 165188.

Widory D; Petelet-Giraud E; Negrel P; Ladouche B. 2005. Tracking the sources of nitrate in groundwater using coupled nitrogen and boron isotopes: a synthesis. Environmental Science and Technology 39, 539-547.

Xue D; Botte J; De Baets B; Accoe F; Nestler A; Taylor P; Van Cleemput O; Berglund M; Boeckx P. 2009. Present limitations and future prospects of stable isotope methods for nitrate source identification in surface- and groundwater. Water Research 43, 1159-1170. 
Table 1. $\delta^{11} \mathrm{~B}$ measurements of standard reference materials used in this study. Recommended values for IAEA-B-2 and IAEA-B-3 from Gonfiantini et al. (2003).

\begin{tabular}{llll}
\hline \hline Batch \# & $\begin{array}{l}\text { SRM 951 } \\
\text { (certified } \\
\text { value }=0.0 \\
\% \text { o) }\end{array}$ & $\begin{array}{l}\text { IAEA-B-2 } \\
\text { (recommended } \\
\text { value }=+14.65 \\
\% \text { ) }\end{array}$ & $\begin{array}{l}\text { IAEA-B-3 } \\
\text { (recommended } \\
\text { value }=-21.37 \\
\% \text { ) }\end{array}$ \\
\hline 1 & -0.01 & 15.29 & -20.50 \\
diff & 0.01 & 0.64 & 0.87 \\
\hline 2 & 0.49 & 15.65 & -19.85 \\
diff & 0.49 & 1.00 & 1.52 \\
\hline 3 & -0.02 & 15.70 & -20.46 \\
diff & 0.02 & 1.05 & 0.91 \\
\hline 4 & 0.71 & 15.78 & -19.62 \\
diff & 0.71 & 1.13 & 1.75 \\
\hline 5 & -0.20 & 14.96 & -21.13 \\
diff & 0.20 & 0.31 & 0.24 \\
\hline 6 & 0.07 & 12.05 & -21.55 \\
diff & 0.07 & 2.60 & 0.18 \\
\hline \hline
\end{tabular}


Eppich, Singleton, Wimpenny, Yin, and Esser (2012) LLNL-TR-533174

Table 2. Reproducibility of $\delta^{11} \mathrm{~B}$ measurements of field duplicates measured in this study.

\begin{tabular}{lll}
\hline \hline Sample ID & Collection Date & $\delta^{11} \mathrm{~B}(\%$ ) \\
\hline SD 831 & $05 / 20 / 2008$ & 42.30 \\
SD 1831 & $05 / 20 / 2008$ & 41.13 \\
difference & & 1.17 \\
\hline
\end{tabular}


Table 3. Total procedural duplicates for groundwater samples measured in this study.

\begin{tabular}{|c|c|c|}
\hline Sample ID & Run \# & $\delta^{11} \mathrm{~B}(\% \circ)$ \\
\hline \multirow[t]{2}{*}{ SD 816} & 1 & 24.66 \\
\hline & 2 & 24.63 \\
\hline difference & & 0.03 \\
\hline \multirow[t]{2}{*}{ SD 920} & 1 & 36.93 \\
\hline & 2 & 37.05 \\
\hline difference & & 0.12 \\
\hline \multirow[t]{2}{*}{ SD 923} & 1 & 24.31 \\
\hline & 2 & 24.99 \\
\hline difference & & 0.68 \\
\hline \multirow[t]{2}{*}{ SD 890} & 1 & 37.54 \\
\hline & 2 & 37.75 \\
\hline difference & & 0.21 \\
\hline \multirow[t]{2}{*}{ SD 945} & 1 & 38.60 \\
\hline & 2 & 38.28 \\
\hline difference & & 0.32 \\
\hline \multirow[t]{2}{*}{ SD 946} & 1 & 6.55 \\
\hline & 2 & 4.28 \\
\hline difference & & 2.27 \\
\hline \multirow[t]{2}{*}{ SD 843} & 1 & 64.38 \\
\hline & 2 & 62.04 \\
\hline difference & & 2.34 \\
\hline \multirow[t]{2}{*}{ SD 919} & 1 & 60.50 \\
\hline & 2 & 59.29 \\
\hline difference & & 1.21 \\
\hline
\end{tabular}


Table 4. Boron concentration and isotopic composition of groundwater samples. Nitrate and boron concentration data from Geotracker GAMA Database.

\begin{tabular}{|c|c|c|c|c|c|}
\hline \multirow[t]{2}{*}{ Sample } & \multirow[t]{2}{*}{$\begin{array}{l}\text { Collection } \\
\text { Date }\end{array}$} & \multirow[t]{2}{*}{ Location } & \multirow{2}{*}{$\begin{array}{l}\mathrm{NO}_{3} \\
\mathrm{mg} / \mathrm{L}\end{array}$} & \multirow{2}{*}{$\begin{array}{c}\mathrm{B} \\
\mu \mathrm{g} / \mathrm{L}\end{array}$} & \multirow{2}{*}{$\begin{array}{c}\delta^{11} B \\
\% \\
\end{array}$} \\
\hline & & & & & \\
\hline SD 801 & $4 / 29 / 2008$ & Ramona & 249 & 77 & 46.6 \\
\hline SD 811 & $5 / 6 / 2008$ & Ramona & 57 & 42 & 25.3 \\
\hline SD 814 & $5 / 7 / 2008$ & Ramona & 111 & 83 & 52.2 \\
\hline SD 816 & $5 / 8 / 2008$ & Ramona & 113 & 133 & 24.7 \\
\hline SD 819 & $5 / 13 / 2008$ & Ramona & 67.2 & 190 & 14.1 \\
\hline SD 820 & $5 / 13 / 2008$ & Ramona & 140 & 78 & 41.6 \\
\hline SD 823 & $5 / 14 / 2008$ & Ramona & 162 & 116 & 39.1 \\
\hline SD 831 & $5 / 20 / 2008$ & Ramona & 50.9 & 83 & 42.3 \\
\hline SD 838 & $5 / 27 / 2008$ & El Cajon & 56.7 & 274 & 33.8 \\
\hline SD 842 & $5 / 28 / 2008$ & Fallbrook & 55.2 & 53 & 53.7 \\
\hline SD 843 & $5 / 28 / 2008$ & Fallbrook & 89.2 & 56 & 64.4 \\
\hline SD 844 & $5 / 28 / 2008$ & Fallbrook & 72.8 & 67 & 53.2 \\
\hline SD 845 & $5 / 29 / 2008$ & El Cajon & 31.7 & 255 & 37.8 \\
\hline SD 848 & $5 / 28 / 2008$ & Fallbrook & 28.5 & 123 & 37.2 \\
\hline SD 850 & $5 / 6 / 2008$ & Ramona & 47.3 & 106 & 36.5 \\
\hline SD 851 & $5 / 28 / 2008$ & Fallbrook & 2.9 & 29 & 35.9 \\
\hline SD 852 & $5 / 28 / 2008$ & Valley Center & 0 & 145 & 24.3 \\
\hline SD 857 & $6 / 4 / 2008$ & Fallbrook & 7.65 & 215 & 42.7 \\
\hline SD 858 & $6 / 5 / 2008$ & El Cajon & 64.9 & 412 & 34.8 \\
\hline SD 860 & $6 / 5 / 2008$ & Lakeside & 0 & 176 & 43.7 \\
\hline SD 861 & $6 / 10 / 2008$ & Lakeside & 45 & 170 & 40.1 \\
\hline SD 862 & $6 / 10 / 2008$ & Lakeside & 5.97 & 186 & 28.0 \\
\hline SD 863 & $6 / 10 / 2008$ & Lakeside & 6.28 & 61.9 & 28.5 \\
\hline SD 864 & $6 / 10 / 2008$ & Lakeside & 87.3 & 99.5 & 46.7 \\
\hline SD 865 & $6 / 10 / 2008$ & Lakeside & 72.9 & 130 & 37.5 \\
\hline SD 870 & $6 / 11 / 2008$ & El Cajon & 17.3 & 134 & 42.9 \\
\hline SD 872 & $6 / 12 / 2008$ & Alpine & 51.2 & 136 & 35.2 \\
\hline SD 873 & $6 / 12 / 2008$ & El Cajon & 26.7 & 193 & 25.7 \\
\hline SD 874 & $6 / 12 / 2008$ & Alpine & 14.7 & 61 & 31.7 \\
\hline SD 877 & $6 / 17 / 2008$ & Alpine & 106 & 326 & 24.8 \\
\hline SD 880 & $6 / 17 / 2008$ & Descanso & 0 & 108 & 29.0 \\
\hline SD 886 & $6 / 18 / 2008$ & Descanso & 42.5 & 104 & 30.6 \\
\hline SD 889 & $6 / 18 / 2008$ & Boulevard & 18.1 & 96.6 & 31.4 \\
\hline SD 890 & $6 / 19 / 2008$ & Boulevard & 117 & 93.5 & 37.5 \\
\hline SD 895 & $6 / 19 / 2008$ & Campo & 5.77 & 161 & 15.8 \\
\hline SD 896 & $6 / 19 / 2008$ & Campo & 7.39 & 187 & 14.1 \\
\hline SD 897 & $5 / 29 / 2008$ & Pala & 5.81 & 78.1 & 40.5 \\
\hline SD 901 & $12 / 2 / 2008$ & Jamul & 16.4 & 170 & 19.0 \\
\hline SD 902 & $12 / 2 / 2008$ & Campo & 43.5 & 44 & 34.9 \\
\hline SD 907 & $12 / 3 / 2008$ & Alpine & 81.6 & 56 & 38.8 \\
\hline SD 908 & $12 / 3 / 2008$ & Jamul & 0 & 41 & 24.1 \\
\hline SD 909 & $12 / 3 / 2008$ & Boulevard & 22 & 74 & 34.5 \\
\hline SD 912 & $12 / 4 / 2008$ & Dulzura & 2.49 & 70 & 31.1 \\
\hline SD 917 & $12 / 9 / 2008$ & Rancho Santa Fe & 0 & 150 & 22.7 \\
\hline SD 918 & $12 / 9 / 2008$ & Escondido & 49.9 & 306 & 40.9 \\
\hline SD 919 & $12 / 9 / 2008$ & Escondido & 84.5 & 211 & 60.5 \\
\hline SD 920 & $12 / 10 / 2008$ & Escondido & 203 & 209 & 36.9 \\
\hline SD 921 & $12 / 10 / 2008$ & Escondido & 0 & 141 & 49.7 \\
\hline SD 923 & $12 / 11 / 2008$ & Valley Center & 21.5 & 106 & 24.3 \\
\hline
\end{tabular}


Eppich, Singleton, Wimpenny, Yin, and Esser (2012) LLNL-TR-533174

\begin{tabular}{cccccc}
\hline Sample & $\begin{array}{c}\text { Collection } \\
\text { Date }\end{array}$ & Location & $\mathrm{NO}_{3}$ & $\mathrm{~B}$ & $\delta^{11} \mathrm{~B}$ \\
& & & $\mathrm{mg} / \mathrm{L}$ & $\mu \mathrm{g} / \mathrm{L}$ & $\%$ \\
\hline SD 927 & $12 / 17 / 2008$ & Ramona & 0 & 194 & 9.1 \\
SD 931 & $12 / 17 / 2008$ & Vista & 31 & 283 & 41.1 \\
SD 933 & $1 / 6 / 2009$ & Santa Ysabel & 14.7 & 162 & 23.7 \\
SD 937 & $12 / 18 / 2008$ & Warner Springs & 0 & 607 & 5.1 \\
SD 942 & $12 / 18 / 2008$ & Santa Ysabel & 0 & 295 & -0.8 \\
SD 945 & $1 / 6 / 2009$ & Campo & 3.04 & 57 & 38.6 \\
SD 946 & $1 / 8 / 2009$ & Borrego Springs & 0 & 1110 & 6.5 \\
\hline
\end{tabular}




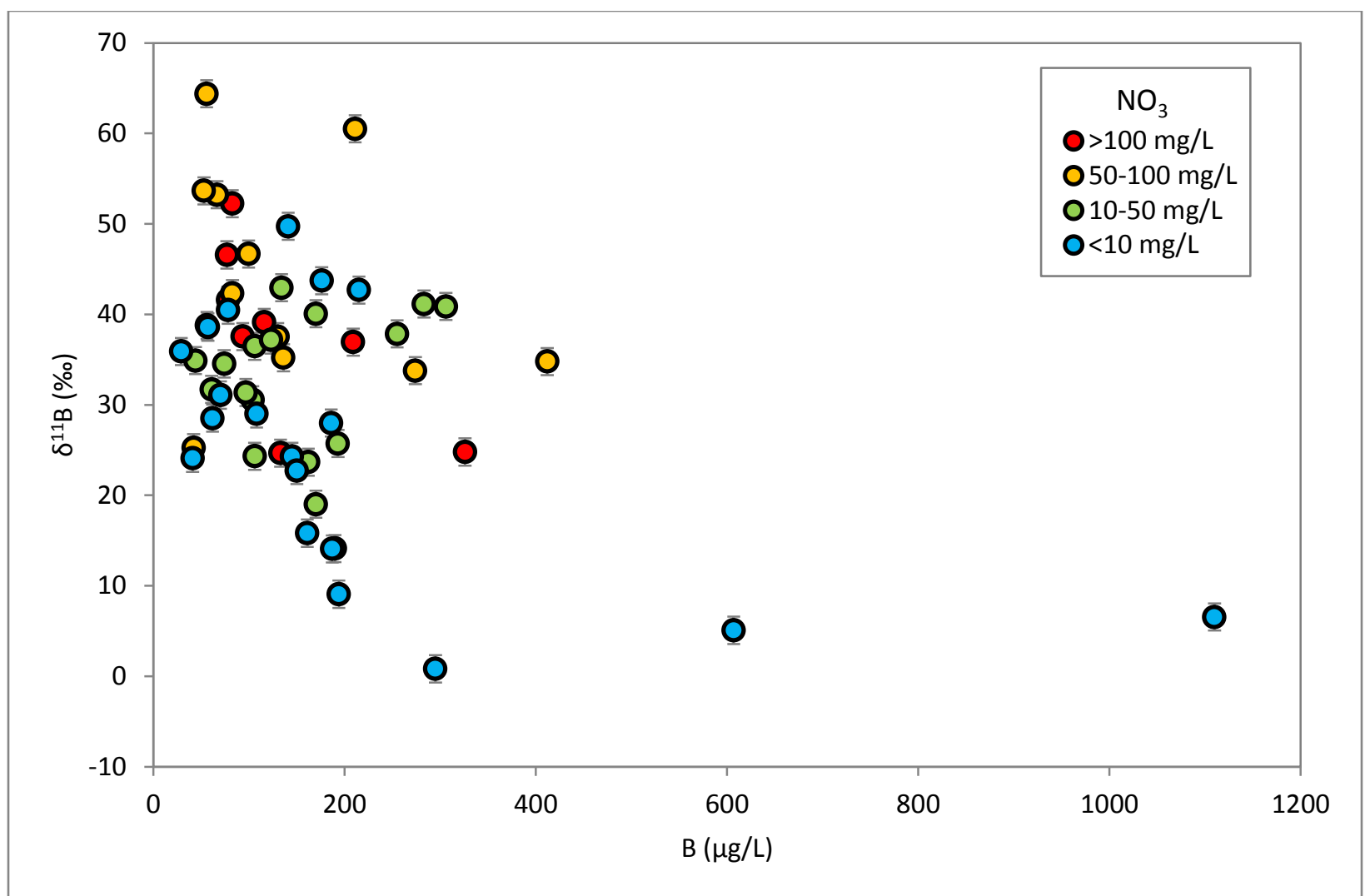

Figure 1. Boron concentration and isotopic composition of San Diego County groundwater samples. Symbol color refers to $\mathrm{NO}_{3}$ concentration (see legend). $\delta^{11} \mathrm{~B}$ is reported relative to NIST SRM 951. Boron and nitrate concentration data are from the Geotracker GAMA Database. 


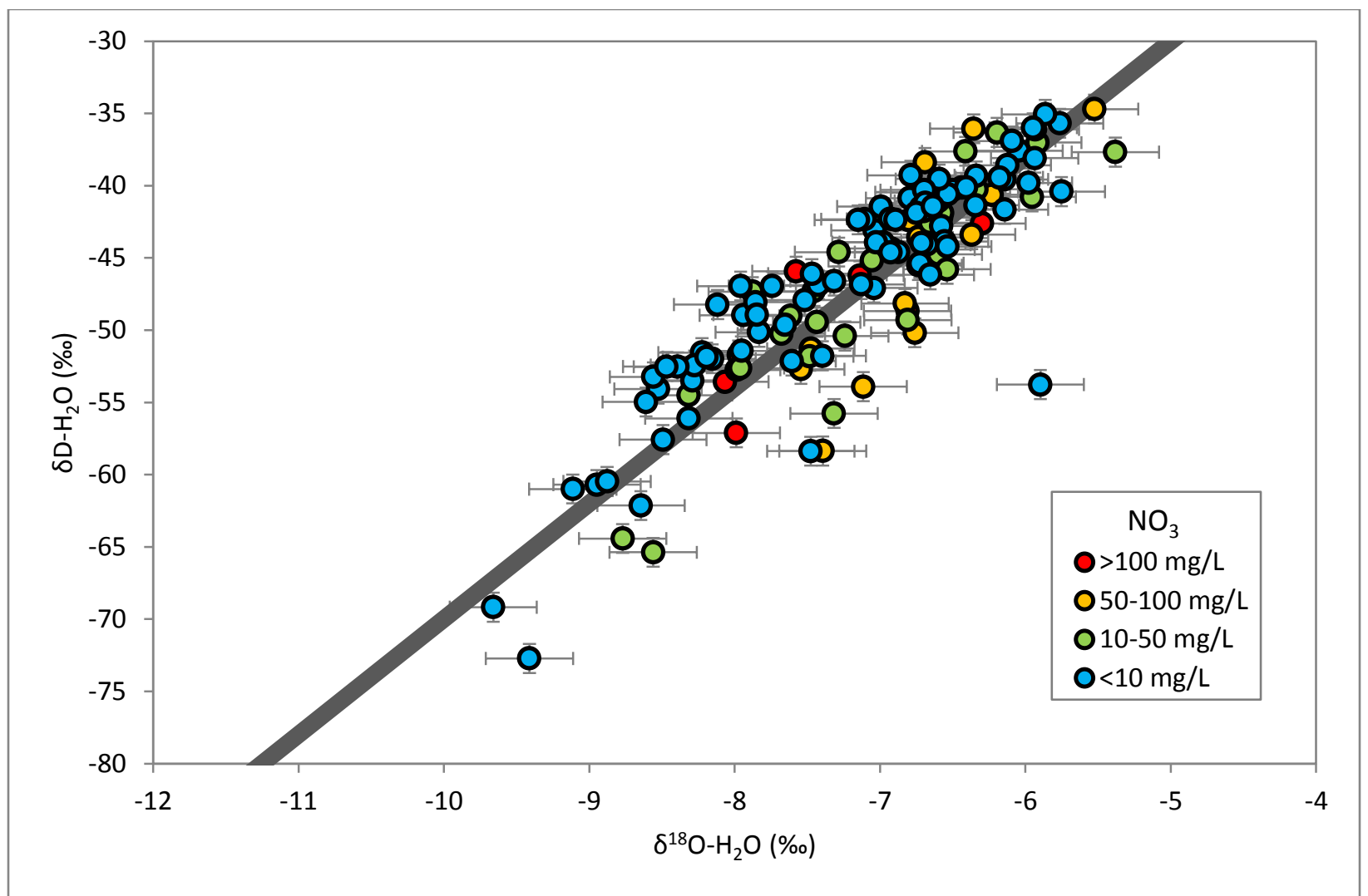

Figure 2. Water isotopic composition $\left(\delta \mathrm{D}, \delta^{18} \mathrm{O}\right)$ of groundwater samples. Symbol color refers to $\mathrm{NO}_{3}$ concentration (see legend). $\delta \mathrm{D}$ and $\delta^{18} \mathrm{O}$ are reported relative to V-SMOW. Gray line is the Global Mean Water Line (Craig, 1961). Isotopic data are from Singleton et al. (2010). Nitrate concentration data are from the Geotracker GAMA Database. 


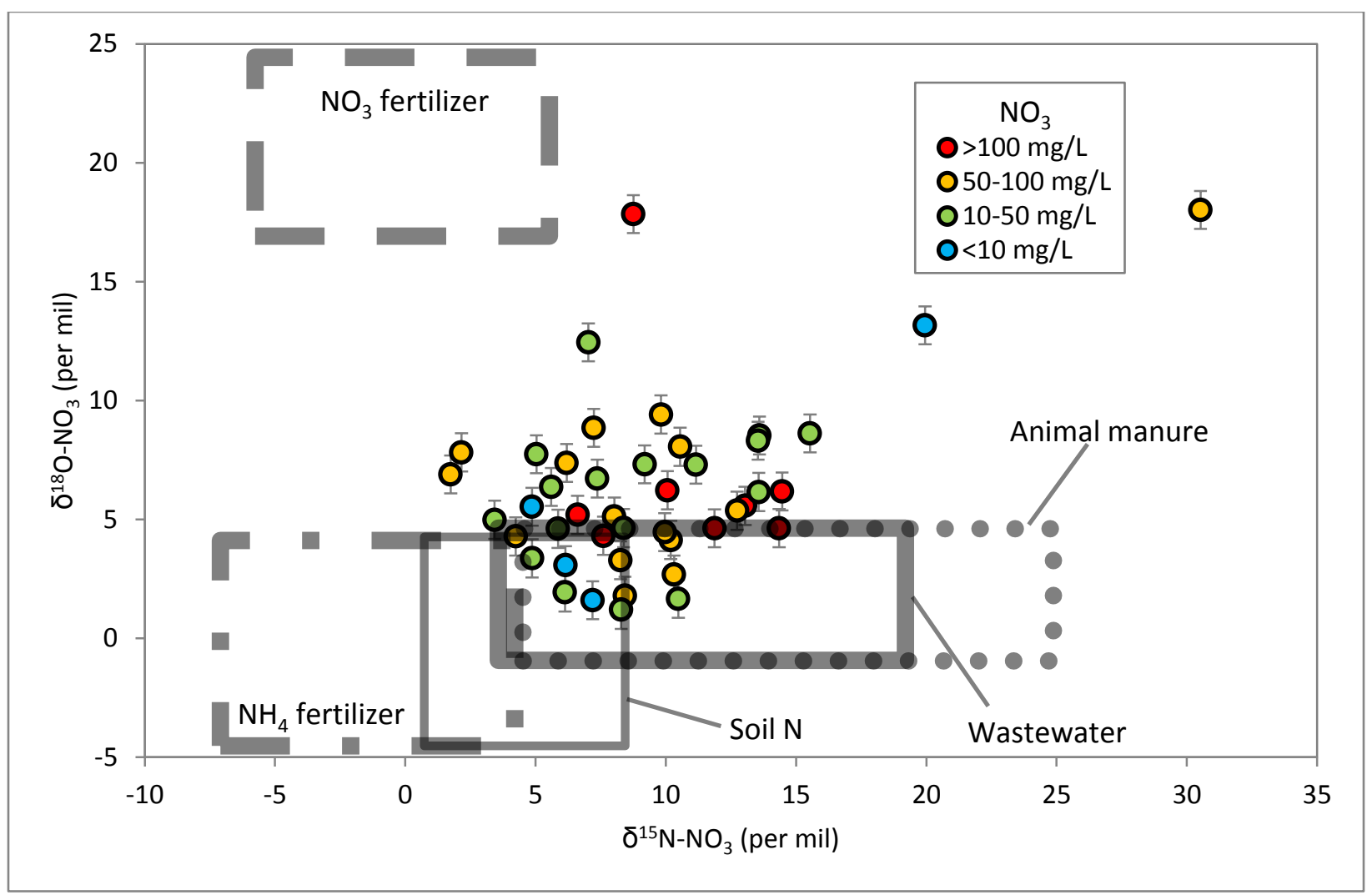

Figure 3. Nitrate isotopic composition $\left(\delta^{18} \mathrm{O}, \delta^{15} \mathrm{~N}\right)$ of groundwater samples. Symbol color refers to $\mathrm{NO}_{3}$ concentration (see legend). $\delta^{15} \mathrm{~N}$ is reported relative to air; $\delta^{18} \mathrm{O}$ is reported relative to $\mathrm{V}$-SMOW. Gray boxes represent fields of isotopic composition from Kendall, 1998 and Xue et al., 2009. Horizontal error bars are smaller than the symbols. Isotopic data are from Singleton et al. (2010). Nitrate concentration data are from Geotracker GAMA Database. 


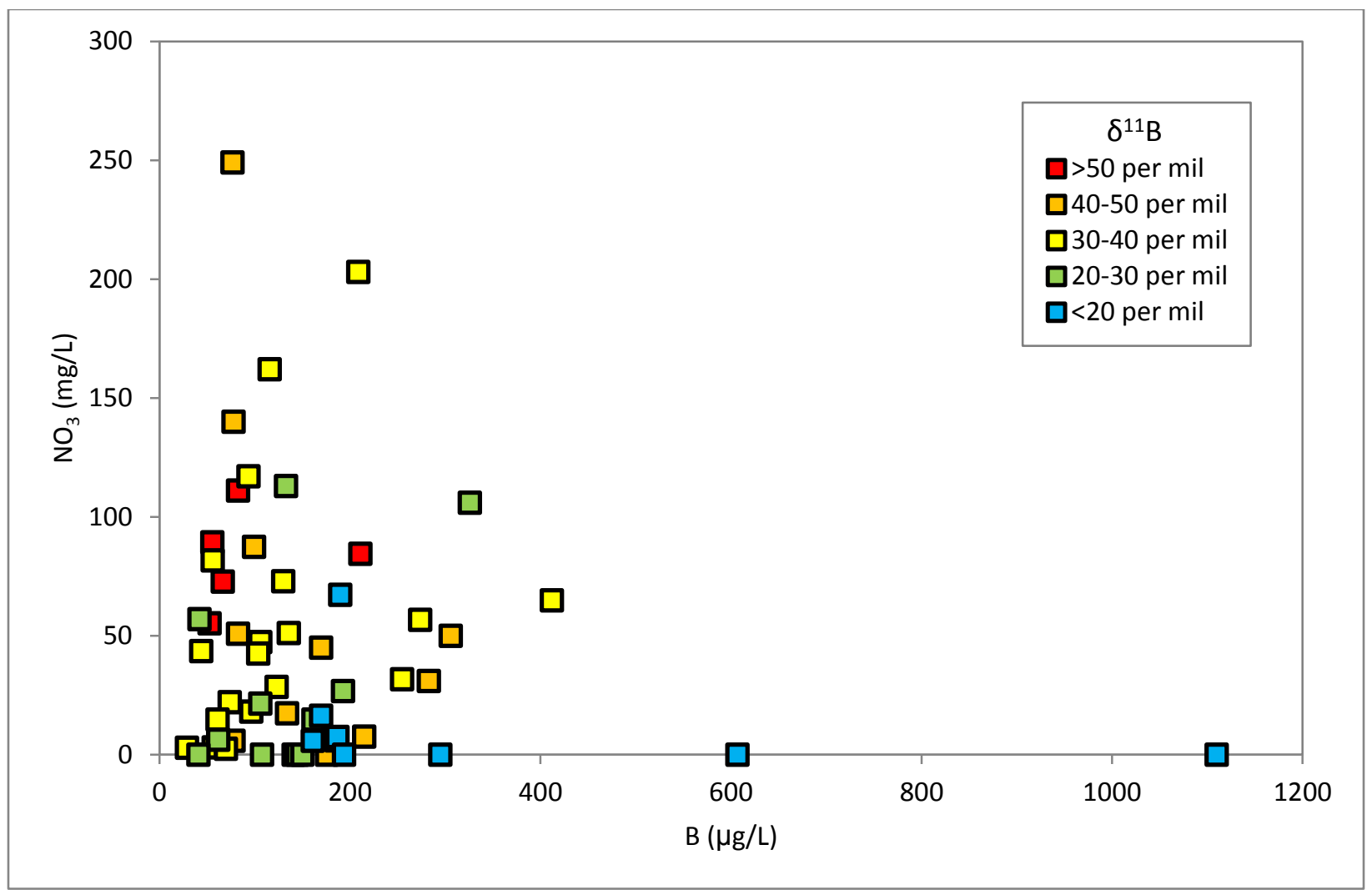

Figure 4. Boron and nitrate concentration of groundwater samples. Symbol color refers to boron isotopic composition (see legend). $\delta^{11} \mathrm{~B}$ is reported relative to NIST SRM 951. Boron and nitrate concentration data are from the Geotracker GAMA Database. 


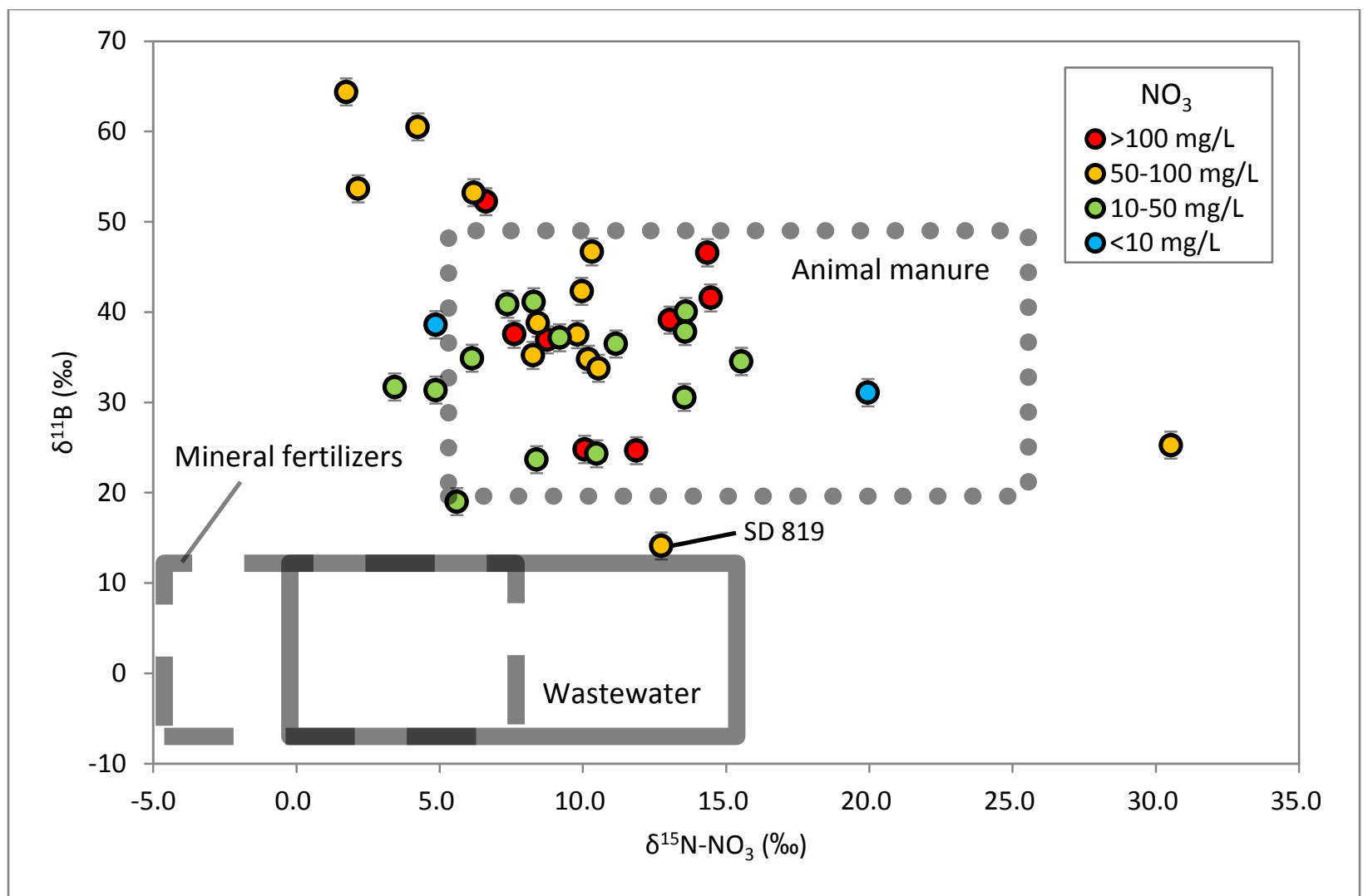

Figure 5. Boron and nitrate isotopic composition of groundwater samples. Symbol color refers to nitrate concentration (see legend). Nitrate isotope data is reported relative to air; boron isotope data are reported relative to NIST SRM 951. Horizontal error bars are smaller than the symbols. Gray boxes represent fields of isotopic composition; nitrate isotope fields are from Kendall, 1998 and Xue et al., 2009. Fields for boron isotopic composition compiled from measurements of wastewater, animal manure, and mineral fertilizers (Vengosh et al., 1994; Bassett et al., 1995; Vengosh et al., 1995; Eisenhut and Heumann, 1997; Komor, 1997; Leenhouts et al., 1998; Widory et al., 2004; Chetelat and Gaillardet, 2005; Seiler, 2005; Accoe et al., 2008; Tirez et al., 2010). Nitrogen isotopic data from Singleton et al., (2010). Nitrate concentration data are from Geotracker GAMA Database. 


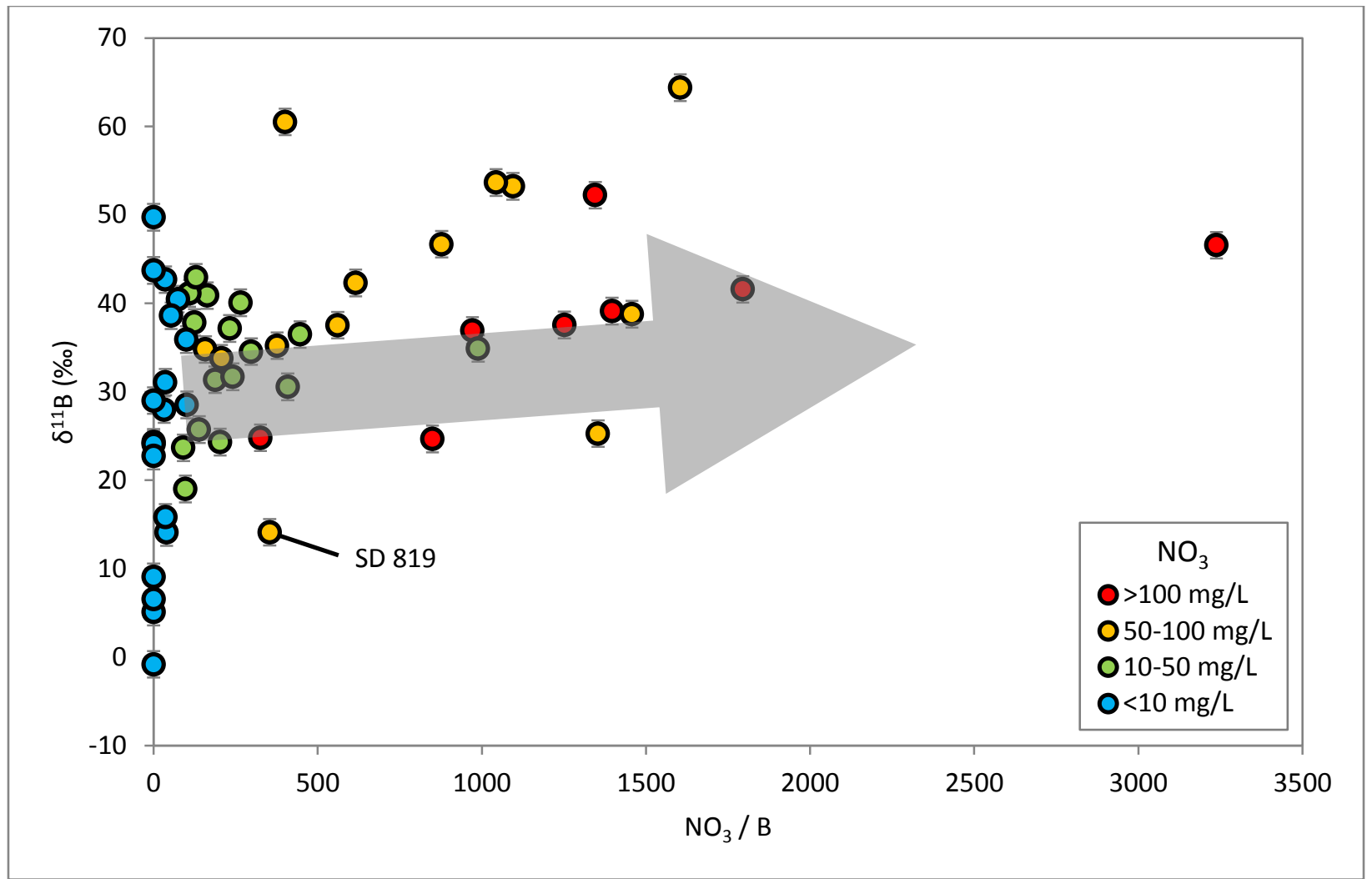

Figure 6. Boron isotopic composition and nitrate/boron ratio of groundwater samples. Symbol color refers to nitrate concentration (see legend). Solid gray arrow represents trend of increasing anthropogenic contamination. Boron and nitrate concentration data are from Geotracker GAMA Database. 